\title{
HUBUNGAN PENYEDIAAN RUANG ASI DAN PEMANFAATANNYA TERHADAP KEBERHASILAN ASI EKSKLUSIF DI UNIVERSITAS AL MUSLIM BIREUEN-ACEH
}

\author{
Nurhidayati, Siti Saleha \\ Universitas Almuslim \\ nurhidayatiibrahim64@gmail.com
}

\begin{abstract}
Abstrak
Capaian ASI Eksklusif tahun 2020 di Kabupaten Bireuen menunjukkan mengalami penurunan dari 47\% pada tahun 2019 (Profil Kesehatan Aceh Tahun 2018, 2019) turun menjadi 39 \% pada tahun 2020 (Dinas Kesehatan Aceh, 2021) sedangkan data capaian Puskesmas Peusangan berjumlah 115 kasus dari 284 sasaran PKM Peusangan, 2021. Adapun Tujuan dari penelitian adalah mengetahui hubungan antara penyediaan ruang ASI dan pemanfaatannya terhadap keberhasilan pemberian ASI Eksklusif di Universitas Almuslim Bireuen Provinsi Aceh. Tinjauan Teori : ASI merupakan sumber gizi yang untuk bayi dengan komposisi seimbang dan sesuai dengan pertumbuhan bayi. Metode Penelitian: penelitian ini bersifat korelasi dengan pendekatan waktu retrospektif yaitu menanyakan kembali riwayat pemberian ASI. Populasi adalah Seluruh ibu yang memiliki anak usia 6-24 bulan yang bekerja di Universitas Almuslim yang berjumlah 68 orang. Hasil Penelitian ini adalah Penyediaan ruang ASI sebanyak (79\%), Memanfaatkan Ruang ASI sebanyak 65\%, Keberhasilan ASI Eksklusif sebanyak 76\% dan Tidak berhasil ASI Eksklusif sebanyak 24\%. Tidak ada hubungan antara penyediaan ruang ASI dengan keberhasilan ASI Eksklusif dengan nilai Asymp. Sig. (2-sided) $(0,379)>$ sig_ $\alpha=0,05$ sedangkan ada hubungan antara pemanfaatan ruang ASI dengan keberhasilan ASI Eksklusif dengan nilai Asymp. Sig. (2-sided) $(0,036)<$ sig_ $\alpha=0,05$. Kesimpulan, tidak terdapat hubungan antara penyediaan ruang ASI dengan keberhasilan ASI Eksklusif dan Terdapat hubungan antara pemanfaatan ruang ASI dengan keberhasilan ASI Eksklusif. Saran, diharapkan dapat digunakan sebagai salah satu sumber data untuk penelitian selanjutnya dan diharapkan dapat meneliti dengan variabel dan desain dan tempat lain yang berhubungan dengan ruang ASI dan ASI Eksklusif.
\end{abstract}

Kata Kunci : Asi Eksklusif, Ruang ASI, Pemanfaatan Ruang ASI. 
JOURNAL OF MIDWIFERY CARE :

VOL. 02 No. 01, DESEMBER 2021

DOI : $\underline{10.34305 / J M C . V 2 I 01.386}$
Ciptaan disebarluaskan di bawah

Lisensi Creative Commons Atribusi-

NonKomersial-BerbagiSerupa 4.0

\section{Pendahuluan}

Air Susu Ibu (ASI) merupakan sumber gizi tinggi yang sangat bermanfaat untuk kesehatan bayi, bahkan World Health Organization (WHO) menyatakan bahwa ASI Eksklusif sangat penting bagi bayi selama enam bulan pertama (Khotimah et al., 2014) (Moneca Diah L, Risma Aliviani P, 2019). Data Badan Kesehatan Dunia (WHO) tahun 2016 masih menunjukkan rata-rata angka pemberian ASI eksklusif di dunia baru berkisar 38 persen. Namun di Indonesia, hanya 42\% bayi yang berusia sampai 6 bulan yang mendapatkan ASI Eksklusif dan berkurang persentase pemberian ASI saat bayi berusia dua tahun yaitu sebesar 35\% (Santi, Mina Yumei, Sabar Santoso, 2020).

Pemerintah Indonesia mengatur masalah ASI Eksklusif dalam Perundangundangan dan peraturan yang didasarkan pada pasal 28B (2) UUD 1945 dan Undang-Undang no 36 tahun 2009 tentang Kesehatan dan Peraturan Pemerintah No 33 tahun 2012 tentang Pemberian Air Susu Ibu Eksklusif. Selain itu untuk mendukung program menyusui di tempat kerja, Pemerintah mengeluarkan peraturan atas dasar pasal Pasal 27 (2) UUD 1945 dengan menerbitkan peraturan-peraturan seperti berikut: UU no 39 tahun 1999 tentang Hak
Asasi Manusia, UU No. 13 tahun 2003 Tentang Ketenagakerjaan, Peraturan Bersama Menteri Pemberdayaan Perempuan RI, Menteri Tenaga Kerja dan Transmigrasi RI dan Menteri Kesehatan RI Nomor 48/Men.PP/XII/2008, Per.27/MEN/XII/2008 dan nomor 1177/Menkes/PB/XII/2008 tentang Peningkatan Pemberian Air Susu Ibu Selama Waktu Kerja di Tempat Kerja (Menteri Tenaga Kerja Dan Transmigrasi, 2008).

Bentuk dari dukungan pemerintah Indonesia untuk meningkatkan cakupan pemberian ASI terdapat pada kebijakan yaitu Peraturan Pemerintah No 33 Tahun 2012 tentang pemberian ASI eksklusif. Pada BAB V telah disebutkan bahwa tempat kerja dan tempat sarana umum harus mendukung program ASI eksklusif dengan menyediakan fasilitas khusus menyusui/memerah ASI dan peraturan ini dilanjutkan dengan Permenkes Nomor 15 tahun 2013 tentang tata cara penyediaan fasilitas khusus menyusui dan/atau memerah ASI (Kemenkes RI, 2013).

Menurut Profil Kesehatan Aceh tahun 2019 (Profil Kesehatan Aceh Tahun 2019, 2020), capaian ASI eksklusif di Aceh tahun 2019 sebesar 55\%, jumlah ini 
JOURNAL OF MIDWIFERY CARE :

VOL. 02 No. 01, DESEMBER 2021

DOI : $\underline{10.34305 / J M C . V 2 I 01.386}$
Ciptaan disebarluaskan di bawah

Lisensi Creative Commons Atribusi-

NonKomersial-BerbagiSerupa 4.0 terjadi penurunan dari tahun sebelumnya sebesar 61\%. Aceh Barat Daya merupakan kabupaten/kota terendah pencapaian ASI Eksklusif yaitu $0 \%{ }^{5}$. Sedangkan Kabupaten Bireuen adalah kabupaten ke 8 terendah pencapaian ASI Eksklusif yaitu 47\%, sedangkan Subulussalam merupakan kabupaten tertinggi pencapaian ASI Eksklusif yaitu 100\%. Capaian ASI Eksklusif tahun 2020 di Kabupaten Bireuen menunjukkan penurunan yang sangat signifikan yaitu dari $47 \%$ pada tahun 2019 turun menjadi $39 \%$ pada tahun 2020 (Dinas Kesehatan Aceh, 2021) sedangkan data capaian Puskesmas Peusangan berjumlah 115 kasus dari 284 sasaran PKM Peusangan, 2021.

Penelitian yang dilaksanakan oleh Suparman, EF dengan judul "Hubungan Pemanfaatan Ruang Laktasi dengan Keberhasilan Pemberian ASI Eksklusif pada Ibu Bekerja di PT Pindad (Persero)" dengan desain penelitian kuantitatif dengan menggunakan rancangan penelitian analitik dan desain cross sectional. Jumlah populasi pada penelitian ini adalah seluruh ibu yang memiliki anak 6-24 bulan dan bekerja di PT Pindad berjumlah 30 Ibu bekerja. Hasil penelitian menunjukkan lebih dari setengah $(63,3 \%)$ atau sebanyak $19 \mathrm{ibu}$ bekerja memanfaatkan ruang laktasi dan sebagian besar $(83,3 \%)$ atau sebanyak 25 ibu bekerja memberikan ASI eksklusif. Dari uji bivariat chi-square didapatkan nilai $\rho$-value $0,04<\alpha 0,05$ yang berarti ada hubungan Pemanfaatan Ruang Laktasi dengan Keberhasilan Pemberian ASI Eksklusif pada Ibu Bekerja di PT Pindad (Persero) (Subratha,2019).

\section{Metode}

Penelitian ini menggunakan metode pendekatan kualitatif dengan desain crosssectional study dengan cara pendekatan observasi atau pengumpulan data sekaligus pada suatu saat (point time approach), yaitu suatu pendekatan yang bersifat sesaat pada suatu waktu. Dengan pengambilan data secara retrospectif yaitu dengan cara menanyakan kembali riwayat pemberian ASI pada ibu yang memiliki anak usia 6-24 bulan yang bekerja di Universitas Almuslim.

Populasi dalam penelitian ini adalah dosen dan staf wanita yang bekerja dan sudah berkeluarga dan memiliki anak usia 06 - 24 bulan (2 tahun) dan masih menyusui yang berjumlah sebanyak 68 orang. Sampel dalam penelitian ini sebanyak 68 responden dan teknik total sampling dimana seluruh populasi dijadikan sampel penelitian. Penelitian ini 
dilaksanakan di Universitas Almuslim Kabupaten Bireuen Aceh. Sebagai dasar pertimbangan memilih lokasi penelitian ini adalah karena di Universitas Almuslim banyak dosen dan staf wanita yang bekerja dan sudah berkeluarga dan memiliki anak.

\section{Hasil}

1. Karakteristik responden

Karakteristik responden dalam penelitian ini dapat dilihat dalam tabel berikut ini:

Tabel 1. Karakteristik Responden Berdasarkan Umur di Universitas Almuslim Bireuen Tahun 2021

\begin{tabular}{cccc}
\hline No & Kategori Umur & Frekuensi & Persentase (\%) \\
\hline 1 & $20-35$ tahun & 51 orang & $75 \%$ \\
2 & $>35$ tahun & 17 orang & $25 \%$ \\
\hline
\end{tabular}

Berdasarkan tabel 1. diatas bahwa karakteristik responden berdasarkan umur dapat dilihat bahwa yang terbanyak adalah umur 20-35 tahun yaitu sebanyak 51 responden $(75 \%)$ dan umur $>35$ sebanyak 17 responden $(25 \%)$.

\section{Analisa Univariat}

a. Penyediaan Ruang ASI

Hasil penelitian tentang distribusi dari variabel penyediaan ruang ASI didapat hasil sebagai berikut :

Tabel 2. Distribusi Frekuensi Penyediaan Ruang ASI di Universitas Almuslim Tahun 2021

\begin{tabular}{lllc}
\hline No & Kategori & Frekuensi & Persentase (\%) \\
\hline 1 & Ada Ruang ASI & 54 & $79 \%$ \\
2 & Tidak ada ruang ASI & 14 & $21 \%$ \\
\hline & Jumlah & $\mathbf{6 8}$ & $\mathbf{1 0 0 \%}$ \\
\hline
\end{tabular}

Berdasarkan tabel 2. menunjukkan bahwa dari 68 responden, distribusi frekuensi penyediaan ruang ASI yaitu sebanyak 54 responden $(79 \%)$ ada 
penyediaan ruang ASI dan sebanyak 14

ruang ASI.

responden (21\%) tidak ada penyediaan

b. Pemanfaatan Ruang ASI

Hasil penelitian distribusi dari variabel pemanfaatan ruang ASI didapat hasil sebagai berikut:

Tabel 3. Distribusi Frekuensi Pemanfaatan Ruang ASI di Universitas Almuslim Tahun 2021

\begin{tabular}{cccc}
\hline No & Kategori & Frekuensi & Persentase \%) \\
\hline 1 & Memanfaatkan ruang ASI & 44 & $65 \%$ \\
2 & Tidak memanfaatkan ruang ASI & 24 & $35 \%$ \\
\hline & Jumlah & $\mathbf{6 8}$ & $\mathbf{1 0 0 \%}$ \\
\hline
\end{tabular}

Berdasarkan tabel 3. menunjukkan (65\%) memanfaatkan ruang ASI dan bahwa distribusi frekuensi pemanfaatan sebanyak 24 responden (35\%) tidak ada ruang ASI yaitu sebanyak 44 responden manfaatkan ruang ASI.

c. ASI Eksklusif

Hasil penelitian menunjukkan bahwa distribusi dari variabel keberhasilan ASI eksklusif didapat hasil sebagai berikut :

Tabel 4. Distribusi Frekuensi Keberhasilan ASI Eksklusif di Universitas Almuslim Tahun 2021

\begin{tabular}{cccc}
\hline No & \multicolumn{1}{c}{ Kategori } & Frekuensi & Persentase (\%) \\
\hline 1 & Berhasil ASI Eksklusif & 52 & $76 \%$ \\
2 & Tidak berhasil ASI Eksklusif & 16 & $24 \%$ \\
\hline & Jumlah & $\mathbf{6 8}$ & $\mathbf{1 0 0 \%}$ \\
\hline
\end{tabular}

Berdasarkan tabel 4. menunjukkan bahwa distribusi frekuensi keberhasilan ASI Eksklusif yaitu sebanyak 52 responden (76\%) memberikan ASI

3. Analisa Bivariat
Eksklusif dan sebanyak 16 responden (24\%) tidak ada Tidak memberikan ASI eksklusif. 
Analisis bivariat menggunakan uji Pearson Chi-square untuk mengetahui hubungan antara variabel bebas (Penyediaan ruang ASI) dengan variabel terikat (dengan keberhasilan ASI eksklusif) diperoleh hasil sebagai berikut:

Tabel 5. Tabulasi Silang Antara Penyediaan Ruang ASI Dengan Keberhasilan ASI Eksklusif di Universitas Almuslim Tahun 2021

\begin{tabular}{|c|c|c|c|c|c|c|c|}
\hline \multirow{3}{*}{ Penyediaan Ruang ASI } & \multicolumn{4}{|c|}{ ASI eksklusif } & \multirow{2}{*}{\multicolumn{2}{|c|}{ Total }} & \multirow{3}{*}{ Sig $p$} \\
\hline & \multicolumn{2}{|c|}{$\begin{array}{l}\text { Tidak ASI } \\
\text { Eksklusif }\end{array}$} & \multicolumn{2}{|c|}{ ASI Eksklusif } & & & \\
\hline & f & $\%$ & f & $\%$ & $\mathbf{F}$ & $\%$ & \\
\hline Tidak ada Ruang ASI & $\mathrm{f}$ & $\%$ & $\mathrm{~F}$ & $\%$ & $\mathrm{f}$ & $\%$ & \\
\hline Ada Ruang ASI & 5 & 33,7 & 9 & 64,3 & 14 & 100 & 0,379 \\
\hline Total & 13 & 24 & 41 & 76 & 54 & 100 & \\
\hline
\end{tabular}

Berdasarkan tabel 5. dapat dilihat bahwa hasil yang menunjukkan ketersediaan ruang ASI sebanyak 54 responden dengan mayoritas ASI eksklusif sebanyak 41 responden $(76 \%)$, dan tidak memberikan ASI eksklusif 13 responden (24\%). Yang tidak ada ruang ASI sebanyak sebanyak 9 responden $(64,3)$, dan tidak memberikan ASI eksklusif 5 responden (33,7\%). Dari hasil analisa data chi-square didapatkan tidak ada hubungan antara penyediaan ruang ASI dengan keberhasilan ASI Eksklusif dengan nilai Asymp. Sig. (2sided) $(0,379)>\operatorname{sig} \_\dot{\alpha}=0,05$.

\section{4 responden dengan ASI eksklusif}

a. Analisis bivariat menggunakan uji Pearson Chi-square untuk mengetahui hubungan antara variabel bebas (Pemanfaatan ruang ASI) dengan variabel terikat (dengan keberhasilan ASI eksklusif) diperoleh hasil sebagai berikut:

Tabel 6. Tabulasi Silang Antara Pemanfaatan Ruang ASI dengan Keberhasilan ASI Eksklusif di Universitas Almuslim Tahun 2021

\begin{tabular}{|c|c|c|c|c|c|c|c|}
\hline \multirow{3}{*}{ Pemanfaatan Ruang ASI } & \multicolumn{4}{|c|}{ ASI Eksklusif } & \multirow{2}{*}{\multicolumn{2}{|c|}{ Total }} & \multirow{3}{*}{ Sig $p$} \\
\hline & \multicolumn{2}{|c|}{$\begin{array}{l}\text { Tidak ASI } \\
\text { Eksklusif }\end{array}$} & \multicolumn{2}{|c|}{ ASI Eksklusif } & & & \\
\hline & f & $\%$ & f & $\%$ & $f$ & $\%$ & \\
\hline Tidak memanfaatkan & 10 & 41,7 & 14 & 58,3 & 24 & 100 & \\
\hline Memanfaatkan & 8 & 18,1 & 36 & 81,9 & 44 & 100 & 0,036 \\
\hline Total & 18 & 26 & 50 & 74 & 68 & 100 & \\
\hline
\end{tabular}


JOURNAL OF MIDWIFERY CARE :

VOL. 02 No. 01, DESEMBER 2021

DOI : $\underline{10.34305 / J M C . V 2 I 01.386}$
Ciptaan disebarluaskan di bawah

Lisensi Creative Commons Atribusi-

NonKomersial-BerbagiSerupa 4.0
Berdasarkan tabel 6. dapat dilihat bahwa hasil yang menunjukkan pemanfaatan ruang ASI sebanyak 44 responden dengan mayoritas ASI eksklusif sebanyak 36 responden $(81,9 \%)$, dan tidak memberikan ASI eksklusif 8 responden $(18,1 \%)$. Yang tidak memanfaatkan ruang ASI sebanyak 24 responden dengan ASI eksklusif sebanyak 14 responden $(58,3 \%)$, dan tidak memberikan ASI eksklusif 10 responden $(41,7 \%)$. Dari hasil analisa data chi-square didapatkan bahwa ada hubungan antara pemanfaatan ruang ASI dengan keberhasilan ASI Eksklusif dengan nilai Asymp. Sig. (2-sided) $(0,036)<$ sig_ó $=0,05$.

\section{Pembahasan}

Berdasarkan hasil penelitian yang dilakukan peneliti terhadap 68 responden tentang hubungan penyediaan ruang ASI dan pemanfaatannya terhadap keberhasilan ASI eksklusif di Universitas Almuslim Bireuen Aceh tahun 2021, maka peneliti membahas hasil penelitian sebagai berikut :

1. Penyediaan ruang ASI di Universitas Almuslim

Berdasarkan hasil penelitian menunjukkan bahwa distribusi frekuensi penyediaan ruang ASI, mayoritas adalah ada penyediaan ruang ASI sebanyak 54 responden $(79 \%)$ dan tidak ada penyediaan ruang ASI sebanyak 14 responden (21\%).

Tujuan dari penyediaan ruang ASI ini adalah untuk memfasilitasi dan memberikan perlindungan kepada ibu menyusui dalam pemberian ASI Eksklusif sehingga terpenuhi hak anak dalam memperoleh ASI Eksklusif serta meningkatkan peran dan dukungan keluarga, masyarakat, Pemerintah Daerah, dan Pemerintah terhadap pemberian ASI Eksklusif. Untuk para ibu yang bekerja sangat membutuhkan dukungan dari tempat kerja dalam pemberian ASI Eksklusif, keberhasilan pemberian ASI Eksklusif pada ibu yang bekerja salah satunya adalah dengan adanya dukungan dari tempat kerja dengan menyediakan fasilitas khusus untuk menyusui (Darmawan, 2019).

Dalam pasal 20 Ayat 1 Qanun Aceh Nomor 4 Tahun 2010 Tentang Kesehatan dinyatakan bahwa setiap badan usaha wajib menyediakan tempat khusus bagi ibu menyusui, bayi, dan anak balita di lingkungan tempat ibu bekerja. Selanjutnya pada Pasal 2 dinyatakan bahwa kewajiban tersebut harus dilaksanakan secara 
JOURNAL OF MIDWIFERY CARE :

VOL. 02 No. 01, DESEMBER 2021

DOI : $\underline{10.34305 / J M C . V 2 I 01.386}$

bertahap paling lama 5 tahun sejak Qanun diundangkan (Qanun Provinsi Aceh No. 4 Tahun 2010 Tentang Kesehatan, n.d.).

Di Universitas Almuslim belum ada Kebijakan Rektor yang mengatur tentang Penyediaan Ruang ASI, akan tetapi karena di beberapa fakultas banyak pegawai wanita yang bekerja maka penyediaan Ruang ASI merasa penting untuk diadakan mengingat jam bekerja di Fakultas juga sampai sore dan beberapa pegawai juga berasal dari luar Kabupaten Bireuen. Sehingga Fakultas memanfaatkan ruangan yang tidak terpakai dalam kegiatan akademik untuk dijadikan ruang tersebut. Ruang ASI yang tersebut tersedia dengan fasilitas yang beragam, ada yang sudah memadai dan ada yang masih kurang memadai.

2. Pemanfaatan Ruang ASI di Universitas Almuslim

Berdasarkan hasil penelitian menunjukkan opbahwa distribusi frekuensi pemanfaatan ruang ASI yaitu sebanyak 44 responden (65\%) memanfaatkan ruang ASI dan sebanyak 24 responden (35\%) tidak memanfaatkan ruang ASI. Pemanfaatan ruang ASI dapat memenuhi kebutuhan ASI bayi, dapat dilakukan dimana saja, dapat memberikan kenyamanan pada ibu-ibu bekerja untuk menyusui, atau memerah
Ciptaan disebarluaskan di bawah

Lisensi Creative Commons Atribusi-

NonKomersial-BerbagiSerupa 4.0 Internasional.

ASI. Dengan adanya ruang ASI ibu yang bekerja dapat menyeimbangkan antara karir dengan menyusui sebenarnya tergantung dari manajemen waktu ibu.

Asumsi peneliti dalam penelitian ini banyaknya karyawan yang menggunakan Ruang ASI disebabkan karena Universitas adalah unit pelayan kepada masyarakat yang setiap waktu banyak orang yang lalu lalang untuk mendapatkan pelayanan seperti mahasiswa dan alumni, maka para pegawai perlu privasi untuk melakukan kegiatan menyusui dan memerah ASI, sehingga Ruang ASI menjadi prioritas para pegawai ketika melakukan kegiatan tersebut.

Peraturan Universitas Almuslim mengenai kerja adalah pagi masuk jam 08.30, istirahat siang jam 12.30 - 13.30, Sore pulang jam 16.30. Sehingga para pegawai yang berdomisili di luar kota Matang Glumpang Dua akan memanfaatkan Ruang ASI untuk kegiatan memerah ASI selama masa menyusui. Sedangkan bagi pegawai yang tidak memanfaatkan Ruang ASI disebabkan karena mereka berdomisili dekat kampus Universitas Almuslim dan juga beberapa pegawai tinggal di perumahan Dosen yang disediakan Universitas. 
JOURNAL OF MIDWIFERY CARE :

VOL. 02 No. 01, DESEMBER 2021

DOI : $\underline{10.34305 / J M C . V 2 I 01.386}$
Ciptaan disebarluaskan di bawah

Lisensi Creative Commons Atribusi-

NonKomersial-BerbagiSerupa 4.0
2. Keberhasilan ASI eksklusif di Universitas Almuslim

Berdasarkan hasil penelitian menunjukkan bahwa distribusi frekuensi keberhasilan ASI Eksklusif yaitu sebanyak 52 responden (76\%) memberikan ASI Eksklusif dan sebanyak 16 responden (24\%) tidak memberikan ASI eksklusif. Keberhasilan ASI eksklusif merupakan satu upaya peningkatan derajat kesehatan dan kesejahteraan bayi. Menurut WHO dan UNICEF adalah ASI dapat menurunkan angka kematian dan kesakitan pada bayi. Kandungan yang terdapat dalam ASI sangat banyak diantaranya dapat mencegah terjadinya diare dan pneumonia. dengan memberikan ASI eksklusif selama enam bulan pertama sangat bermanfaat pada pertumbuhan dan perkembangan bayi secara optimal.

Hasil penelitian Lidawati $\mathrm{R}$ (Lindawati, 2019) menjelaskan dimana semakin rendah pendidikan seorang ibu akan cenderung gagal memberikan ASI secara eksklusif, begitu juga sebaliknya makin tinggi pendidikan seorang ibu akan semakin tinggi keberhasilan pemberian ASI secara eksklusif. Pendidikan akan berpengaruh besar terhadap pengetahuan seseorang, semakin tinggi pendidikan seseorang akan semakin luas pemahaman dan kemampuan menerima atau mengadopsi perilaku baru.

Persentase pegawai yang memberikan ASI eksklusif di Universitas Almuslim dikategorikan tinggi. Menurut Asumsi Peneliti, keberhasilan ASI eksklusif terjadi karena para pegawai di Universitas memiliki pendidikan minimal S1 untuk staf dan S2, S3 untuk Dosen, sehingga para pegawai sudah memahami tentang pentingnya pemberian ASI Eksklusif untuk bayinya.

4. Hubungan penyediaan ruang ASI dengan keberhasilan ASI eksklusif di Universitas Almuslim

Hasil penelitian ketersediaan ruang ASI sebanyak 54 responden (80\%) dengan mayoritas ASI eksklusif sebanyak 41 responden (61\%), dan tidak memberikan ASI eksklusif 13 responden (19\%). Dari hasil analisa data chi-square didapat tidak ada hubungan antara penyediaan ruang ASI dengan keberhasilan ASI Eksklusif dengan nilai Asymp. Sig. (2-sided) $(0,379)$ $>\operatorname{sig} \_\alpha=0,05$.

Ruang ASI adalah ruangan yang dilengkapi dengan prasarana menyusui dan memerah ASI yang digunakan untuk menyusui bayi, memerah ASI, menyimpan ASI perah, dan/atau konseling menyusui/ASI, Dengan adanya fasilitas 
JOURNAL OF MIDWIFERY CARE :

VOL. 02 No. 01, DESEMBER 2021

DOI : $\underline{10.34305 / J M C . V 2 I 01.386}$

ruang laktasi ini merupakan dukungan terhadap pemenuhan hak ASI Eksklusif baik untuk masyarakat umum maupun di kalangan Ibu bekerja, dapat memberikan kenyamanan kerja bagi pekerja perempuannya memberikan pengaruh terhadap peningkatan produktivitas kerja pekerja perempuan.

Bagi seorang pekerja dalam kondisi menyusui, keberadaan ruang laktasi membantunya dalam menyusui bayi dan memerah ASI sehingga walaupun bekerja ibu tetap dapat memenuhi kebutuhan ASI untuk bayinya. Dengan meningkatnya tenaga kerja perempuan seperti sekarang ini dapat mempengaruhi pemberian ASI Eksklusif kepada bayinya karena dalam bekerja dikhawatirkan mengalami kesulitan dalam pemberian ASI sebab belum mendapatkan kesempatan dalam memberikan ASI di tempat kerjanya.

Menurut asumsi peneliti tidak ada hubungan antara penyediaan ruang ASI dengan keberhasilan ASI Eksklusif, di Universitas Almuslim karena, meskipun ada penyediaan ruang ASI para pegawai yang masih menyusui memerah ASI pada saat dirumah. Karena beberapa pegawai berdomisili di sekitar Universitas, sedangkan pegawai dan dosen yang berasal dari luar daerah memanfaatkan perumahan
Ciptaan disebarluaskan di bawah

Lisensi Creative Commons Atribusi-

NonKomersial-BerbagiSerupa 4.0 Internasional

dosen, karena Almuslim memiliki 50 rumah dinas. Hal ini sejalan dengan penelitian yang dilakukan oleh Subrata, hasil penelitian menunjukkan bahwa tidak ada hubungan hubungan ketersediaan ruang ASI dengan keberhasilan ASI eksklusif (Friska Hesteria, 2019).

5. Hubungan pemanfaatan ruang ASI dengan keberhasilan ASI eksklusif di Universitas Almuslim

Hasil penelitian menunjukkan pemanfaatan ruang ASI sebanyak 44 responden (65\%) dengan mayoritas ASI eksklusif sebanyak 36 responden (54\%) dan analisa data chi-square menunjukkan ada hubungan antara pemanfaatan ruang ASI dengan keberhasilan ASI Eksklusif dengan nilai Asymp. Sig. (2-sided) (0,036) $<\operatorname{sig} \_\alpha_{\alpha}=0,05$. Pemanfaatan ruang ASI sangat mendukung keberhasilan pemberian ASI, salah faktor yang mempengaruhi seorang ibu untuk memanfaatkan ruang laktasi salah satunya adalah ketersediaan fasilitas.

Sejalan dengan penelitian yang dilakukan Feranda, 2019 yang bertujuan untuk mengetahui hubungan pemanfaatan ruang laktasi dengan keberhasilan pemberian ASI Eksklusif pada ibu bekerja di perusahaan. Diperoleh hasil penelitian menunjukkan lebih dari setengah $(63,3 \%)$ 
JOURNAL OF MIDWIFERY CARE :

VOL. 02 No. 01, DESEMBER 2021

DOI : $\underline{10.34305 / J M C . V 2 I 01.386}$

memanfaatkan ruang laktasi dan sebagian besar $(83,3 \%)$ memberikan ASI eksklusif, dan terdapat hubungan antara pemanfaatan ruang laktasi dengan keberhasilan pemberian ASI eksklusif pada ibu bekerja di perusahaan $(P$ value $<0,05)$ dengan analisa bivariat menggunakan Chi-square (Santi, Mina Yumei, Sabar Santoso, 2020).

Berdasarkan hasil penelitian tersebut maka peneliti berasumsi bahwa para pegawai sudah memiliki pengetahuan tentang ASI eksklusif, sehingga memanfaatkan ruang ASI, hal ini sejalan dengan penelitian yang dilakukan oleh Setyorini, tentang faktor-faktor yang mempengaruhi perilaku pemberian Air Susu Ibu (ASI) eksklusif, hasil penelitian menunjukkan ada hubungan pengetahuan responden dengan pemberian ASI Eksklusif (Ria Novita Setyorini, Bagoes Widjanarko, 2017).

Di Universitas Almuslim walaupun belum ada Kebijakan dari Rektor tentang Penyediaan Ruang ASI, tapi mengenai pemberian waktu menyusui khusus untuk menyusui tidak dibatasi, sehingga para pegawai memiliki waktu untuk pulang kerumah bagi yang berdomisili di sekitar kampus dan memerah ASI di Ruang ASI
Ciptaan disebarluaskan di bawah

Lisensi Creative Commons Atribusi-

NonKomersial-BerbagiSerupa 4.0 Internasional

yang disediakan Fakultas bagi pegawai yang berdomisili jauh dari Universitas.

\section{Kesimpulan}

Hasil penelitian menunjukan dari 68 responden didapat mayoritas memiliki penyediaan ruang ASI sebanyak 54 responden (79\%). Hasil penelitian menunjukan dari 68 responden didapat mayoritas memanfaatkan ruang ASI yaitu sebanyak 44 responden (65\%). Hasil penelitian menunjukan dari 68 responden didapat mayoritas memberikan ASI Eksklusif yaitu sebanyak 52 responden (76\%). Tidak terdapat hubungan antara penyediaan ruang ASI dengan keberhasilan ASI Eksklusif dengan nilai Asymp. Sig. (2-sided) $(0,379)>\operatorname{sig} \alpha \dot{\alpha}=0,05$, hasil penelitian diolah dengan menggunakan analisa data chi-square. Terdapat hubungan antara pemanfaatan ruang ASI dengan keberhasilan ASI Eksklusif dengan nilai Asymp. Sig. (2-sided) $(0,036)<$ sig_ó $=0,05$, Hasil penelitian diolah dengan menggunakan analisa data chi-square.

\section{Saran}

1. Saran Kepada Responden

Diharapkan supaya setiap ibu yang menyusui dapat tetap memberikan ASI kepada bayinya, dengan memerah ASI 
JOURNAL OF MIDWIFERY CARE :

VOL. 02 No. 01, DESEMBER 2021

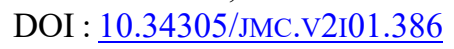

pada saat ibu bekerja dengan memanfaatkan ruang ASI, guna meningkatkan kesejahteraan bayi, karena ASI merupakan makanan yang memiliki nutrisi lengkap yang sesuai dengan kebutuhan bayi.

2. Saran Kepada Tempat Penelitian

Diharapkan pimpinan dapat mengupayakan adanya kebijakan tentang pengadaan ruang ASI di tingkat Universitas dan memberi dukungan kepada setiap pegawai wanita yang sedang menyusui dapat mengoptimalkan pemanfaatan ruang ASI dan tetap memberikan ASI eksklusif kepada bayinya.

3. Saran Kepada Peneliti Selanjutnya

Diharapkan dapat digunakan sebagai salah satu sumber data untuk penelitian selanjutnya dan diharapkan dapat meneliti dengan variabel dan desain dan tempat lain yang berhubungan dengan ruang ASI dan ASI Eksklusif.

\section{Referensi}

Darmawan, D. (2019). Faktor - Faktor Yang Berhubungan Dengan Pemanfaatan Ruang Laktasi Pada Ibu Menyusui Yang Bekerja Di Kementerian Keuangan Ri 2019. Journal Of Chemical Information And Modeling, 53(9), 1689-1699.

Profil Kesehatan Aceh Tahun 2018,
Ciptaan disebarluaskan di bawah

Lisensi Creative Commons Atribusi-

NonKomersial-BerbagiSerupa 4.0 Internasional.

(2019).

Profil Kesehatan Aceh Tahun 2019, (2020).

Dinas Kesehatan Aceh. (2021). Profil Kesehatan Aceh Tahun 2020.

Friska Hesteria, S. A. (2019). Hubungan Ketersediaan Ruang Asi Dengan. Jurnal Medika Usada, 2(2), 60.

Kemenkes RI. (2013). Peraturan Menteri Kesehatan Republik Indonesia Nomor 15 Tahun 2013 Tata Cara Penyediaan Fasilitas Khusus Menyusui Dan/Atau Memerah Air Susu Ibu. Peraturan Menteri Kesehatan, 9. Http://Www.Gizikia.Depkes.Go.Id/ $\mathrm{Wp}$ -

Content/Uploads/Downloads/2013/0 8/Permenkes-No.-15-Th-2013-TtgFasilitas-Khusus-Menyusui-DanMemerah-ASI.Pdf

Khotimah, K., Emilia, O., \& Hakimi, M. (2014). Pemanfaatan Pojok Laktasi Di Puskesmas I Cilongok Kabupaten Banyumas. Jurnal Kesehatan Reproduksi, 1(1), 46-59. Https://Doi.Org/10.22146/Jkr.4914

Lindawati, R. (2019). Hubungan Pengetahuan, Pendidikan Dan Dukungan Keluarga Dengan Pemberian ASI Eksklusif. Faletehan Health Journal, 6(1), 30-36. Https://Doi.Org/10.33746/Fhj.V6i1.2 5

Menteri Tenaga Kerja Dan Transmigrasi, D. M. K. (2008). Peraturan Bersama Menteri Negara Pemberdayaan Perempuan, Menteri Tenaga Kerja Dan Transmigrasi, Dan Menteri 
Kesehatan.

Moneca Diah L, Risma Aliviani P, P. L. (2019). Pentingnya Pojok ASI Bagi Pekerja Buruh Pabrik Di Kecamatan Bergas Kabupaten Semarang. 1(2).

Qanun Provinsi Aceh No. 4 Tahun 2010 Tentang Kesehatan.

Ria Novita Setyorini, Bagoes Widjanarko, A. S. (2017). Faktor-Faktor Yang Mempengaruhi Perilaku Pemberian Faktor Yang Mempengaruhi Perilaku Pemberian Air Susu Ibu (Asi) Eksklusif Di Wilayah Kerja Puskesmas Pegandan Kota Semarang. Jurnal Kesehatan
Masyarakat (E -Journal) Volume 5, Nomor 3, Juli 2017 (Issn: 23563346), 3(2), 620-628.

Santi, Mina Yumei, Sabar Santoso, N. S. (2020). Hubungan Dukungan Tempat Bekerja Dengan Pemberian Asi Eksklusif Pada Ibu Bekerja Di Wilayah Puskesmas Sewon Ii Kabupaten Bantul, Diy. 011, 41-51.

Subratha, H. F. A. (2019). Hubungan Ketersediaan Ruang Asi Dengan Keberhasilan Pemberian Asi Eksklusif Pada Ibu Bekerja Di Tabanan. Jurnal Medika Usada, 2(2), 57-60. 